\title{
PENGARUH PROGRAM PENDIDIKAN MORAL DAN ETIKA TENTARA TERHADAP PENGUASAAN PESERTA
}

\author{
Azri Mokhtar \\ ayuazrie@gmail.com \\ Fakulti Pendidikan Universitas Malaya (UM) Malaysia \\ Wan Hasmah Wan Mamat \\ wanhasmah@um.edu.my \\ Fakulti Pendidikan Universitas Malaya (UM) Malaysia \\ Ghazali Darussalam \\ dragha@um.edu.my \\ Fakulti Pendidikan Universitas Malaya (UM) Malaysia \\ Triyo Supriyatno \\ triyos.70@gmail.com /trios70@yahoo.com \\ Fakultas Ilmu Tarbiyah dan Keguruan UIN Maliki Malang
}

\section{Abstrak:}

Artikel ini membahas kontribusi Moral dan program Militer Etis Pendidikan (MMEE) di Angkatan Bersenjata Malaysia (MAF). Penelitian ini dilakukan untuk menilai pengaruh atau kontribusi program MMEE untuk etika (MME) prestasi moral dan militer di antara para peserta dalam tiga domain kognitif, afektif dan psikomotorik. Sebanyak 469 peserta mengambil pencapaian tes MET dan data dianalisis dengan menggunakan analisis regresi berganda. Hasil penelitian menunjukkan bahwa pengaruh program MMEE telah berkontribusi sedikit untuk pencapaian MET peserta $=1,4 \%$. Dalam hal hasil oleh domain masing-masing, kontribusi program MMEE melalui jadwal elemen untuk prestasi kognitif = $1,4 \%$, kontribusi program MMEE melalui elemen silabus untuk prestasi afektif $=3,6 \%$ dan kontribusi dari program MMEE melalui elemen pengajaran dan pembelajaran prestasi psikomotor $=0,5 \%$.

Kata kunci: Kontribusi, program MMEE, prestasi MME, kontribusi program Abstract:

This article discusses the contribution of Moral and Military Ethical Education programs (MMEE) in the Malaysian Armed Forces (MAF). This study was conducted to assess the influence or contribution of the MMEE's program for moral and military ethical (MME) achievement among the participants in the three domains of cognitive, affective and psychomotor. A total of 469 
participants took the MET test achievement and the data were analyzed using multiple regression analysis. The results showed that the influence of MMEE's program has contributed a little to MET achievement of the participant $=1.4 \%$. In terms of breakdown by domain, the contribution of the MMEE's program through schedule element for cognitive achievement $=1.4 \%$, the contribution of the MMEE's program through syllabus element for affective achievement $=3.6 \%$ and the contribution of the MMEE's program through teaching and learning elements for psychomotor achievement $=0.5 \%$.

Keywords: Contribution, MMEE's program , MME' achievement , program contribution

\section{Prolog}

Angkatan Tentara Malaysia (ATM) sangat menitik-beratkan aspek kualitas modal insan untuk melahirkan anggota tentara yang kompeten dan memiliki nilai-nilai unggul. Aspirasi ini sangat bertepatan dengan Mattox yang menekankan bahwa nilai akhlak yang tinggi bagi anggota tentara sangat perlu karena bisa menghasilkan satu imperatif moral yaitu memiliki sifat belas kasihan yang mendalam, mementingkan keadilan dan memiliki kewibawaan serta berupaya membedakan antara perlakuan yang mewajarkan keganasan atau sebaliknya sewaktu peperangan. ${ }^{1}$

Menyadari hakikat bahwa sistem latihan melalui pemberian ganjaran dan mengenakan hukuman adalah tidak memadai untuk memastikan tingkah laku moral diamalkan, ${ }^{2}$ maka dengan itu ATM telah memperkenalkan program Pendidikan Moral dan Etika Tentara (PMET) di bawah Pemerintahan Medan Tentara Darat mulai tahun 2006. Langkah ini seiring dengan Konsep Pendidikan ATM yaitu sebagai satu usaha berterusan untuk melahirkan warga ATM yang berilmu pengetahuan dan seimbang dari segi emosi, rohani, intelek dan jasmani. Usaha ini akan menjamin satu proses pendidikan yang berterusan dalam membekalkan pengetahuan dan pengalaman baru ke arah melahirkan anggota tentara yang berpribadi unggul. Tindakan ini seiring dengan pendapat Davidson yaitu, "pendidikan karakter adalah satu proses di mana individu dibina watak melalui interaksi

\footnotetext{
${ }^{1}$ Mattox, J. The moral foundations of Army officership. 387-408. In Snider, D. \& Matthews, L. (2005). The future of the Army profession, $2^{\text {nd }}$ Ed., (New York: McGraw-Hill, 2005)

${ }^{2}$ Martinelli-Fernandez, S. Educating honorable warriors. Journal of Military Ethics, 5(1), 5566. Retrieved Thursday, February 22, 2007 from the Academic Search Premier database. (2006).
} 
domain kognitif yang sedia ada, pengalaman baru dan pengaruh orang di sekeliling mereka". ${ }^{3}$

Dalam meningkatkan keupayaan modal insan ATM agar memenuhi keperluan visinya yaitu Menjadi Sebuah Angkatan Tentara Yang Versatil Pada Abad Ke-21, struktur pendidikan ATM telah menggariskan sebanyak lima kategori pendidikan dalam ATM yaitu Pendidikan Individu, Pendidikan Profesional Tentara, Pendidikan Dalam Latihan, Pengajian Tinggi dan Pendidikan Akhlak. ${ }^{4}$ Menyentuh mengenai pendidikan akhlak, tinjauan kajian mendapati pelaksanaannya perlu diberi penekanan dan diperkemaskan agar kelima-lima struktur pendidikan ATM dapat didukung secara terpadu.

Seiring dengan dasar ATM menetapkan lulus ujian penguasaan Moral dan Etika Tentara (MET) sebagai salah satu daripada syarat kenaikan pangkat bagi anggota yang bukan beragama Islam berlaku tahun 2013, maka pelaksanaan program PMET tersebut telah diperluaskan ke seluruh perkhidmatan dalam ATM yaitu Tentara Darat Malaysia (TDM), Tentara Laut Di-Raja Malaysia (TLDM) dan Tentara Laut Di-Raja Malaysia (TUDM). Bagi memenuhi aspirasi ini, pelakasaan program Pendidikan Moral dan Etika Tentara (PMET) harus dinilai semula agar pelaksanaannya mampu memberi dampak dalam meningkatkan penguasaan Moral dan Etika Tentara (MET) dalam kalangan anggota tentara.

\section{Program PMET Berpengaruh Meningkatkan Penguasaan Peserta}

Nilai budaya ketimuran dalam masyarakat Malaysia kian terkikis berikut berlakunya proses dominasi oleh budaya yang tidak sehat seperti budaya hedonisme dari Barat. Menurut Moha Asri, kemerosotan nilai sosial di kalangan masyarakat di Malaysia bukanlah sesuatu yang baru. Ia dikatakan mula menular dalam kehidupan masyarakat Malaysia pada awal tahun 1960-an. Malah peningkatan gejala kemerosotan nilai sosial ini semakin berkembang pada akhir tahun 1980-an hingga hari ini. ${ }^{5}$ Sebagai sebahagian komunitas dalam masyarakat, anggota ATM juga turut rentan

\footnotetext{
3 Davidson, Harness the sun, channel the wind: The promise and pitfalls of character education in the 21 st century. In D. K Lapsley \& F. C. Power (Eds.), Character psychology and character education (pp. 218-244). Notre Dame, IN: (University of Notre Dame Press. 2005), 227.

${ }^{4}$ Jabatan Arah Pendidikan. Arahan Pentadbiran Pendidikan. (Kuala Lumpur : ATM. 2008.. Arahan Pentadbiran Pendidikan ATM, 2008.

${ }^{5}$ Moha Asri. Pembangunan perindustrian di Malaysia: perkembangan dan permasalahan. Edisi 3, (Shah Alam: Fajar Bakti, 1997).
} 
kepada gejala yang tidak baik ini dan secara tidak langsung turut menyumbang kepada peningkatan statistik gejala sosial negara. ${ }^{6}$

Sebagai salah satu langkah bagi memperkasakan keunggulan diri anggota ATM, maka program PMET harus dipersiapkan supaya pelaksanaannya berpengaruh dan mencapai objektif program. Di dalam menilai sesuatu program pendidikan atau latihan, terdapat pelbagai pendekatan penilaian yang dikemukan oleh pakar-pakar penilaian program untuk melihat tahap keberpengaruhan suatu program. Stufflebeam dan Shinkfield berpendapat bahwa pendekatan penilaian boleh dibagikan kepada pendekatan penilaian pseudo, penilaian kuasi dan penilaian autentik. ${ }^{7}$ Trochim berpendapat bahwa terdapat empat pendekatan dalam melaksanakan penilaian program yaitu berdasarkan orientasi model penelitian saintifik, sistem pengurusan, antropologi atau model kualitatif dan peserta program. ${ }^{8}$ Kajian ini telah mengadaptasi Model Logik Universitas Winconsin dan Model Hammond. Model logik adalah cara visual yang menggambarkan teori perubahan. ${ }^{9}$ Menurutnya, teori perubahan menerangkan bagaimana sekumpulan pencapaian awal dan pertengahan menetapkan peringkat untuk menghasilkan keputusan jangka panjang. Model ini diadaptasi bagi melihat sejauhmanakah keupayaan elemen-elemen program PMET dalam memberi dampak. Memandangkan kajian ini bertujuan untuk melihat keberpengaruhan program terhadap tujuan yaitu tahap penguasaan MET anggota peserta dalam ketiga-tiga domain yaitu kognitif, afektif dan psikomotor, maka kajian ini juga turut mengadaptasi Model Hammond.

Keberpengaruhan sesuatu program akan dipengaruhi oleh input atau sumber yang terdapat dalam program tersebut seperti proses pengajaran dan pembelajaran, kemudahan, silabus, jadwal dan tempat. Dari segi keberpengaruhan proses pengajaran dan pembelajaran (PdP) pula, ia bergantung kepada kesesuaian dalam penyusunan jadwal waktu seperti yang dinyatakan oleh Fauziah dalam Azizi. ${ }^{10}$ Menurut Fauziah, di sinilah

\footnotetext{
${ }^{6}$ Markas Medan Tentera Darat. Statistik Kes Jenayah dan Dadah Pemerintahan Medan Tentera Darat, Sel Provos. (2012).

${ }^{7}$ Stufflebeam, D. L. \& Shinkfield, A. J. Systematic evaluation - a self instructional guide to theory and practice, (Boston: Kluwer Nijhoff Publishing, 1990).

${ }^{8}$ Trochim, W. K. Intoduction to evaluation. http://trochim.human.cornell.edu. (1999). 13 April 200.

9 Frechtling, J.A. Logic Modeling Methods in Program Evaluation, (San Francisco, CA: Jossey-Bass, 2007)

${ }^{10}$ Azizi Yahya. The Using of Model Context. Input, Process and Products (CIPP) In Learning Programs Assessment. International Conference on Challenges and Prospects in Teacher Education, Concorde Hotel : Shah Alam ( 16 \& 17 July 2001). (2001b).
} 
terletaknya kemahiran dan pengetahuan pegawai pelaksana sesuatu program atau pengelola sekolah dalam menyusun jadwal waktu agar ia sesuai dengan kehendak guru yang mengajar mata pelajaran tersebut. Jadwal waktu yang sistematik kurang menimbulkan masalah kepada guru-guru terutamanya dari segi kelicinan proses pengajaran dan pembelajaran. Pelaksanaan program dalam suasana tempat yang tidak nyaman dan kekurangan peralatan atau ketidaksesuaian peralatan yang digunakan waktu mengajar akan memberi pengaruh kepada penguasaan atau pencapaian peserta.

Pelaksanaan program yang menekankan aspek kemudahan yang mencukupi dan sesuai serta nyaman akan menjurus kepada keberpengaruhan proses pengajaran dan pembelajaran. Kent memaparkan fakta bahwa kekurangan sumber dan kemudahan dalam perlaksanaan sesuatu program boleh mempengaruhi tahap pencapaian dan keberpengaruhan program tersebut. ${ }^{11}$ Kajian Shaw mendapati pencapaian tingkah laku kognitif, afektif dan perlakuan dapat dipengaruhi oleh metode pengajaran yang digunakan dalam sesuatu kursus. Memandangkan metode pengajaran yang dipilih oleh pengajar memberi dampak kepada pencapaian pelajar, maka langkahlangkah perlu harus diambil dengan melakukan penilaian terhadap metode pengajaran. ${ }^{12}$

Penilaian proses pengajaran adalah tertumpu kepada proses yang digunakan untuk mencapai objektif dan tujuan program. Kajian Cage mendapati pemilihan metode pengajaran yang akan digunakan dalam pengajaran dan pembelajaran oleh seseorang pengajar boleh mempengaruhi tingkah laku pelajar. ${ }^{13}$ Menurut Ulrich dan Cole, pemilihan metode pengajaran yang tepat boleh memberi pengaruh kepada pencapaian tujuan sesuatu program. Pemilihan metode pengajaran adalah berbeda-beda mengikut keadaan dan keperluan yang berkaitan dengan objektif yang bertarget. ${ }^{14}$ Dalam hal ini, Reece dan Walker berpendapat dalam melakukan sesuatu pengajaran, para pengajar harus memilih metode yang sesuai dengan gaya pelajar dan tujuan pengajaran. Dengan itu, Reece dan Walker mengemukakan satu jadwal strategi mengajar dan gaya pembelajaran yaitu

\footnotetext{
${ }^{11}$ Kent, C.A., Introduction: educating the Heffalump. In: C.A. Kent (ed.), Entrepreneurship Education:Current Developments, Future Directions, New York: Quorum books, 1990, hlm. $1-26$.

${ }^{12}$ Shaw. Assesing Student Enterprise Capabilities. Evaluation Practice in the Enterprise for Higher Education Initutive. (1992).University of Bristol: hlm. 3-5.

${ }^{13}$ Cage, N. The evaluation of teaching effectiveness and teacher education. Proceedings International for Education Seminar. 30 September-4 Oktober 1974, UNESCO. (1975).

${ }^{14}$ Ulrich, T. A., and Cole, G. S. Toward More Effective Training of Future Entrepreneurs', JSBM, 25 (4), (1987), pp32-39.
} 
kesesuaian metode pengajaran yang harus dipilih mengikut keperluan tahap domain pembelajaran, baik kognitif, afektif atau perlakuan. ${ }^{15}$

Teori Perkembangan Moral Kognitif menyatakan bahwa perubahan dalam pertimbangan moral adalah berdasarkan tahap yaitu seseorang dihadapkan pertimbangan moralnya dan tidak memadai jika hanya mengambil satu metode pendidikan moral untuk membangunkan pertimbangan moral. Teori ini juga menyatakan bahwa pembangunan moral memerlukan pelajar mengambil peranan dengan menjiwai dan bersimpati dengan orang lain. Instrumen ini telah disahkan secara empiris melalui perbincangan dilema kumpulan kecil. ${ }^{16}$

Dalam konteks ketentaraan tidak banyak penelitian empiris dijalankan mengenai keberpengaruhan pendidikan karakter dan pendidikan moral dalam tentara. ${ }^{17}$ Beliau menyatakan hanya sedikit penelitian dijalankan bagi menangani kemerosotan aspek karakter, keberpengaruhan proses melahirkan anggota tentara bermoral dan persediaan untuk melakukan yang sepatutnya dalam suasana peperangan dan kehidupan masyarakat sipil. Untuk melahirkan seorang perwira, angkatan tentara itu tidak boleh sekedar memberi tumpuan kepada latihan ketentaraan semata-mata, namun sebagai sebahagian daripada rakyat sesebuah negara, anggota tentara sepatutnya menjadi warganegara teladan. ${ }^{18}$ Anggota tentara mesti menjadi contoh moral di dalam suasana peperangan maupun dalam keadaan aman. Mereka mesti berpegang teguh kepada nilai-nilai tentara dan nilai-nilai nasional semasa menjalankan tugas.

Nilai akhlak yang tinggi sangat perlu karena ianya menuntut satu imperatif moral yaitu memiliki sifat belas kasihan yang mendalam, mementingkan keadilan dan memiliki kewibawaan serta berupaya membedakan antara perlakuan yang mewajarkan keganasan atau sebaliknya semasa peperangan. ${ }^{19}$ Kajian Azri menunjukkan pencapaian kognitif bagi anggota tentara program PMET adalah pada tahap sederhana yaitu nilai min 2.417 dan deviasi piawai 0.969 , pencapaian afektif adalah pada tahap

\footnotetext{
${ }^{15}$ Reece dan Walker. Teaching Training and Learning: A Practical Guide (3rd ed). London: Business Education Publisher. (1997).

${ }^{16}$ Bebeau, M. The Defining Issues Test and the four component model: Contributions to professional education. Journal of Moral Education, 31(3), (2002). hlm. 271-295.

${ }^{17}$ Williams. The Effect of Initial Entry Training on The Moral and Character Development of Military Police Soldiers. Ph.D Thesis, Walden University. (2010)

${ }^{18}$ Snider, D. Ethics and the human development of the soldier spirit.The Army Chaplaincy, (2008).hlm. 23-33.

${ }^{19}$ Mattox, J. The moral foundations of Army officership. (2005).387-408. In Snider, D. \& Matthews, L. (2005). The future of the Army profession, $2^{\text {nd }}$ Ed., New York: McGraw-Hill.
} 
memuaskan dengan nilai min 4.137 dengan deviasi piawai 0.777 dan bagi pencapaian psikomotor pula adalah pada tahap baik dengan nilai purata min 2.24 dan deviasi piawai 0.860. Dari segi perbedaan pencapaian dan latar belakang individu pula, pencapaian kognitif menunjukkan wanita hampir sama dengan anggota lelaki, bagi pencapaian afektif tentara wanita menunjukkan pencapaian afektif lebih ketara berbanding lelaki manakala pencapaian tingkah laku pula menunjukkan tentara lelaki lebih tinggi mengatasi wanita. Seterusnya kajian tersebut menunjukkan bahwa, persepsi anggota tentara terhadap dimensi pengajaran yaitu metode pengajaran dan kemudahan program pada tahap amat memuaskan dengan masing-masing nilai min 4.208 dan 4.226 serta nilai deviasi piawai 0.704 dan 0.721. Bagi pengurusan organisasi adalah pada tahap memuaskan dengan nilai min 4.042 dan deviasi piawai $0.818 .^{20}$

Kajian Williams juga menunjukkan kandungan dan metode Latihan Awal Kemasukan Polisi Tentara seolah-olah tidak mempunyai pengaruh pertimbangan moral tentara, sebaliknya cenderung untuk mengekalkan norma skema pertimbangan moral yaitu pendekatan yang berasaskan peraturan untuk membuat keputusan moral. Menurutnya, hubungan pemimpin dan anggota bawahan muncul sebagai pengaruh yang paling utama terhadap keberpengaruhan pendidikan moral dan pendidikan karakter. Budaya tentara didapati cenderung menjadi penghalang dalam membangunkan pertimbangan moral yang diperlukan untuk masa depan operasi ketentaraan yang lebih fleksibal. ${ }^{21}$

\section{Metode Penelitian}

Desain kajian ini adalah kajian tinjauan yaitu menggunakan instrumen kuesioner dan ujian penguasaan MET untuk melihat keberpengaruhan program PMET yang dilaksanakan dalam ATM. Kuesioner disediakan sebanyak tiga set yang berlainan dan dikemukan kepada anggota peserta, fasilitator dan pemerintah pasukan. Bagi ujian penguasaan MET pula hanya dikemukan kepada anggota peserta sahaja.

Fokus kajian ini adalah untuk mendapat tanggapan daripada responden terhadap keberpengaruhan program PMET yang dijalankan dalam ATM. Sampel kajian ini merupakan populasi sebenarnya anggota peserta,

\footnotetext{
${ }^{20}$ Azri. Pelaksanaan Program Pendidikan Moral dan Etika Pemerintahan Medan Tentera Darat. Tesis Sarjana. Fakulti Pendidikan, Universitas Malaya. (2009).

${ }^{21}$ Williams. The Effect of Initial Entry Training on The Moral and Character Development of Military Police Soldiers. Ph.D Thesis, Walden University.2010
} 
fasilitator dan pemerintah yang terlibat dengan program PMET pada bulan September hingga Desember 2013. Sampel kajian ini merangkumi keempatempat divisi penempatan anggota ATM. 1 Divisi adalah penempatan di Sabah dan Sarawak, 2 Divisi merupakan penempatan di Utara Semenanjung Malaysia, 3 Divisi di Selatan Semenanjung Malaysia dan 4 Divisi di Bahagian Tengah Semenanjung Malaysia. Pecahan populasi sampel kajian mengikut penempatan anggota dalam ATM seperti rajah berikut:

Jadwal 1: Bilangan Sampel Anggota Peserta, Fasilitator dan Pemerintah Mengikut Divisi

\begin{tabular}{lccc}
\hline Divisi & Anggota Peserta & Fasilitator & Pemerintah Pasukan \\
\hline 1 Divisi & 220 & 6 & 5 \\
2 Divisi & 138 & 8 & 7 \\
3 Divisi & 59 & 8 & 8 \\
4 Divisi & 52 & 11 & 11 \\
\hline JUMLAH & 469 & 33 & 32 \\
\hline
\end{tabular}

Teknik Analisis

Dalam kajian ini, proses menganalisis data melibatkan dua jenis statistik yaitu deskriptif dan inferensi. Untuk menjalankan analisis, proses pengkodean akan dijalankan untuk memudahkan aktivitas memasukkan data. Data statistik deskriptif digunakan untuk melihat dan menghuraikan secara menyeluruh tentang latar belakang responden seperti bangsa, jantina, umur, taraf perkawinan, pangkat yang disandang, lama perkhidmatan dalam ATM, lama mengajar PMET, lama menjawat jawatan sekarang dan kelulusan akademik. Skor, kekerapan, perat usan, min dan sisihan lazim akan dilihat dalam analisis statistik deskriptif ini.

Statistik inferensi pula untuk membuat anggaran tentang satu indeks populasi dengan menggunakan satu indeks statistik dari satu sampel yang representatif. ${ }^{22}$ Berdasarkan persoalan kajian, analisis yang akan dijalankan dalam statistik inferensi kategori ANOVA Satu Arah dan Regresi Berganda. Prosedur statistik dicipta bagi membandingkan kumpulan berasaskan kepada

\footnotetext{
22 Alias Baba. Statistik untuk penyelidikan dalam pendidikan dan sains sosial. Bangi: Penerbit Universiti Kebangsaan Malaysia. 1992.
} 
variabel terikat yang diminati. ${ }^{23}$ Sekiranya bilangan kumpulan melebihi dua, maka kebiasaannya ANOVA atau analisis varian menjadi pilihan untuk menganalisis data. Analisis ANOVA ialah ujian berparameter dan kerap digunakan dalam analisis kuantitatif yang dikaitkan dengan taburan atau prosedur F. ${ }^{24}$ Analisis Regrasi Berganda pula digunakan untuk melihat dampak variabel bebas dan variabel antara terhadap penguasaan MET anggota peserta bagi ketiga-tiga domain kognitif, afektif dan psikomotor. Analisis ini merupakan metode statistik untuk menentukan hubungan yang wujud secara linear antara variabel bebas dan variabel terikat. ${ }^{25}$

\section{Hasil Penelitian}

Pengaruh program PMET adalah adalah merujuk kepada keupayaan elemen-elemen utama program PMET dalam menyumbang kepada peningkatan penguasaan MET anggota peserta silabus, jadwal, kemudahan, tempat dan PdP. Jadwal 2 hingga 5 adalah data analisis regresi berganda yang dijalankan pada aras signifikan 0.05 yang menunjukkan perkaitan atau kontribusi program PMET terhadap penguasaan MET anggota peserta (kognitif, afektif dan psikomotor). Hipotesis mengenai kontribusi elemenelemen utama terhadap penguasaan kognitif adalah seperti berikut:

Ho.1 Tidak terdapat kontribusi yang signifikan oleh silabus program PMET terhadap penguasaan kognitif.

Ho.2 Tidak terdapat kontribusi yang signifikan oleh jadwal program PMET terhadap penguasaan kognitif.

Ho.3 Tidak terdapat kontribusi yang signifikan oleh kemudahan program PMET terhadap penguasaan kognitif.

Ho.4 Tidak terdapat kontribusi yang signifikan oleh tempat pelaksanaan program PMET terhadap penguasaan kognitif.

Ho.5 Tidak terdapat kontribusi yang signifikan PdP program PMET terhadap penguasaan kognitif.

Bagi penguasaan aspek kognitif, Jadwal 2 menjelaskan kesemua elemen program PMET menunjukkan hubungan yang tidak signifikan yaitu nilai $\mathrm{P}^{-} 0.05$ kecuali elemen jadwal. Data menunjukkan elemen jadwal menghasilkan nilai Beta $=0.202$, nilai $\mathrm{t}=2.641$ dan nilai $\mathrm{P}=0.009$. Analisis regresi berganda seterusnya menunjukkan nilai $\mathrm{R}$ bagi jadwal $=$

\footnotetext{
${ }^{23}$ Black, T. R. Doing quantitative research in the social sciences - an integrated approach to research design, measurement and statistics. London: Sage Publications. 1999.

${ }^{24}$ Lim. Penelitian pendidikan: Pendekatan kuantitatif dan kualitatif. Shah Alam: McGrawHill (Malayasia) Sdn. Bhd. 2007.

${ }^{25}$ Alias Baba, 1992
} 
0.194 , $R$ ganda $2=0.037$ dan nilai ralat piawai $=2.075$. Nilai korelasi $(R)$ yang ditunjukkan adalah kuat, yaitu terdapat hubungan di antara kedua variabel yang dikaji yaitu jadwal dan penguasaan kognitif. Gradien yang positif ini menunjukkan korelasi kedua-dua variabel adalah berkadar terus. Seterusnya apabila nilai pekali korelasi dikuasaduakan, maka $\mathrm{R}$ ganda $2=$ 0.037. Data ini menunjukkan jumlah varians yang disatukan bersama oleh variabel tersebut ialah $3.7 \%$. Selanjutnya nilai $\mathrm{R}$ diubah suai $=0.014$. Dengan ini dapatan analisis regresi berganda menunjukkan keberpengaruhan program PMET yang disumbang oleh elemen jadwal program terhadap penguasaan kognitif anggota peserta $=1.4 \%$.

Dapatan kajian ini telah membuktikan bahwa andaian tidak terdapat kontribusi yang signifikan oleh silabus, kemudahan, tempat dan PdP program PMET terhadap penguasaan kognitif (Ho.1, Ho.3, Ho4 dan Ho.5) adalah tidak berhasil ditolak. Sebaliknya andaian tidak terdapat kontribusi yang signifikan oleh jadwal program PMET terhadap penguasaan kognitif (Ho.2) berhasil ditolak. Justeru, Ho.1, Ho.3 Ho.4 dan Ho.5 adalah diterima (tidak berhasil ditolak) dan Ho.2 adalah tidak diterima (berhasil ditolak).

Jadwal 2 : Analisis Regresi Berganda Kontribusi Elemen Program PMET Terhadap Penguasaan Kognitif

\begin{tabular}{|l|l|r|r|r|r|r|}
\hline $\begin{array}{c}\text { Penguasa } \\
\text { an }\end{array}$ & \multicolumn{1}{|c|}{ Elemen } & \multicolumn{1}{c|}{$\mathrm{B}$} & $\begin{array}{c}\text { Ralat } \\
\text { Piawaii }\end{array}$ & Beta & $\mathrm{T}$ & Sig \\
\hline Kognitif & Silabus & - & .336 & -.085 & -.993 & .321 \\
& Jadwal & .333 & .253 & .202 & 2.641 & .009 \\
& Kemudahan & .668 & .237 & .017 & .216 & .829 \\
& Tempat & .051 & .294 & -.046 & -.550 & .583 \\
& PdP & - & .499 & -.133 & - & .297 \\
& Analisis & .162 & & & 1.045 & \\
& Regresi & .521 & Ganda & ai R & Ralat & $1.4 \%$ \\
& & & 2 & 0.014 & Piawai & \\
& & $\mathrm{R}$ & 0.037 & & 2.075 & \\
& & 0.194 & & & & \\
\hline
\end{tabular}


Hipotesis mengenai kontribusi elemen utama terhadap penguasaan afektif adalah seperti berikut:

Ho.6 Tidak terdapat kontribusi yang signifikan oleh silabus program PMET terhadap penguasaan afektif.

Ho.7 Tidak terdapat kontribusi yang signifikan oleh jadwal program PMET terhadap penguasaan afektif.

Ho.8 Tidak terdapat kontribusi yang signifikan oleh kemudahan program PMET terhadap penguasaan afektif.

Ho.9 Tidak terdapat kontribusi yang signifikan oleh tempat pelaksanaan program PMET terhadap penguasaan afektif.

Ho.10 Tidak terdapat kontribusi yang signifikan PdP program PMET terhadap penguasaan afektif.

Untuk penguasaan afektif, Jadwal 3 mendapati kesemua elemen program PMET menunjukkan hubungan yang tidak signifikan yaitu nilai $\mathrm{P}$ 0.05 kecuali elemen silabus. Kajian mendapati pengaruh elemen silabus terhadap penguasaan afektif telah menghasilkan nilai Beta $=0.207$, nilai $\mathrm{t}=$ 2.459 dan nilai $\mathrm{P}=0.014$. Analisis seterusnya menunjukkan secara nilai $\mathrm{R}=$ 0.244 , $R$ ganda $2=0.060$ dan nilai ralat piawai $=4.29$. Nilai korelasi $(R)$ yang ditunjukkan adalah kuat, yaitu terdapat hubungan di antara kedua variabel yang dikaji yaitu silabus dan penguasaan afektif. Gradien yang positif ini menunjukkan korelasi kedua-dua variabel adalah berkadar terus. Seterusnya apabila nilai pekali korelasi dikuasaduakan, maka $\mathrm{R}$ ganda dua $=$ 0.060. Data ini menunjukkan jumlah varians yang disatukan bersama oleh variabel tersebut ialah $6.0 \%$. Seterusnya apabila nilai $\mathrm{R}$ diubah suai $=$ 0.036. Dengan ini dapatan analisis regresi berganda menunjukkan keberpengaruhan program PMET menerusi kontribusi elemen silabus terhadap penguasaan afektif anggota peserta $=3.6 \%$.

Dapatan kajian ini telah membukti bahwa andaian tidak terdapat kontribusi yang signifikan oleh jadwal, kemudahan dan PdP program PMET terhadap penguasaan afektif (Ho.7, Ho.8, Ho.9 dan Ho.10) tidak berhasil ditolak. Sebaliknya andaian tidak terdapat kontribusi yang signifikan oleh silabus program PMET terhadap penguasaan afektif (Ho.6) berhasil ditolak. Justeru, Ho.7, Ho.8, Ho.9 dan Ho.10 adalah diterima (tidak berhasil ditolak) dan Ho.6 adalah tidak diterima (berhasil ditolak).

Jadwal 3 : Analisis Regresi Berganda Kontribusi Elemen Program PMET Terhadap Penguasaan Afektif 
Pengaruh program pendidikan moral dan etika tentara terhadap penguasaan peserta

\begin{tabular}{|c|c|c|c|c|c|c|}
\hline $\begin{array}{c}\text { Penguasa } \\
\text { an }\end{array}$ & Elemen & B & $\begin{array}{c}\text { Ralat } \\
\text { Piawaii }\end{array}$ & Beta & $\mathrm{T}$ & Sig \\
\hline Kognitif & $\begin{array}{l}\text { Silabus } \\
\text { Jadwal } \\
\text { Kemudahan } \\
\text { Tempat } \\
\text { PdP } \\
\\
\text { Analisis } \\
\text { Regresi }\end{array}$ & $\begin{array}{c}1.706 \\
.299 \\
-.347 \\
-1.115 \\
- \\
1.347 \\
\mathrm{R} \\
0.244\end{array}$ & $\begin{array}{c}.694 \\
.522 \\
.490 \\
.608 \\
1.031 \\
\\
\text { R Ganda } \\
2 \\
0.060\end{array}$ & $\begin{array}{c}- \\
.085 . \\
207 \\
.043 \\
-.055 \\
-.151 \\
-.164 \\
\text { Ubahsuai } \\
\text { R } \\
0.036\end{array}$ & $\begin{array}{c}2.45 \\
9 \\
\cdot \\
573 \\
- \\
.708 \\
- \\
1.83 \\
4 \\
-1.307 \\
\text { Ralat } \\
\text { Piawai } \\
4.290\end{array}$ & $\begin{array}{r}.014 \\
.567 \\
.479 \\
.067 \\
.192 \\
\\
\text { Kontribusi } \\
3.6 \%\end{array}$ \\
\hline
\end{tabular}

Hipotesis mengenai kontribusi elemen utama terhadap penguasaan psikomotor adalah seperti berikut:

Ho.11 Tidak terdapat kontribusi yang signifikan oleh silabus program PMET terhadap penguasaan psikomotor

Ho.12 Tidak terdapat kontribusi yang signifikan oleh jadwal program PMET terhadap penguasaan psikomotor.

Ho.13 Tidak terdapat kontribusi yang signifikan oleh kemudahan program PMET terhadap penguasaan psikomotor 
Ho.14 Tidak terdapat kontribusi yang signifikan oleh tempat pelaksanaan program PMET terhadap penguasaan psikomotor.

Ho.15 Tidak terdapat kontribusi yang signifikan PdP program PMET terhadap penguasaan psikomotor.

Bagi penguasaan psikomotor pula, Jadwal 4 menunjukkan kesemua elemen program PMET adalah tidak signifikan yaitu nilai $\mathrm{P}^{-} 0.05$ kecuali elemen PdP. Data menunjukkan analisis PdP terhadap penguasaan aspek psikomotor mendapati nilai Beta $=-0.261$, nilai $\mathrm{t}=-2.043$ dan nilai $\mathrm{P}=$ 0.042 . Analisis seterusnya menunjukkan nilai $\mathrm{R}=0.170, \mathrm{R}$ ganda dua $=$ 0.029 dan nilai ralat piawai $=3.99$. Nilai korelasi $(R)$ yang ditunjukkan adalah kuat, yaitu terdapat hubungan di antara kedua variabel yang dikaji yaitu PdP dan penguasaan psikomotor. Kecerunan yang positif ini menunjukkan korelasi kedua-dua variabel adalah berkadar terus. Seterusnya apabila nilai pekali korelasi dikuasaduakan, maka $\mathrm{R}$ ganda dua $=0.029$. Data ini menunjukkan jumlah varians yang dikongsi bersama oleh variabel tersebut ialah $2.9 \%$. Seterusnya setelah nilai $\mathrm{R}$ disesuaikan, didapati nilai $\mathrm{R}$ disesuaikan $=0.005$. Dengan ini dapatan analisis regresi berganda menunjukkan keberpengaruhan program PMET mengikuti kontribusi elemen PdP program terhadap penguasaan psikomotor anggota peserta $=0.5$ $\%$.

Dapatan kajian ini telah membukti bahwa andaian tidak terdapat kontribusi yang signifikan oleh silabus, jadwal dan kemudahan program PMET terhadap penguasaan psikomotor (Ho.11, Ho.12 Ho.13 dan Ho.14) adalah tidak berhasil ditolak. Sebaliknya andaian tidak terdapat kontribusi yang signifikan oleh PdP program PMET terhadap penguasaan kognitif (Ho.15) berhasil ditolak. Justeru, Ho.11, Ho.12, Ho.13 dan Ho.14 adalah diterima (tidak berhasil ditolak) dan Ho.15 adalah tidak diterima (berhasil ditolak).

Jadwal 4 : Analisis Regresi Berganda Kontribusi Elemen Program PMET Terhadap Penguasaan Psikomotor

\begin{tabular}{|l|l|c|c|c|c|c|}
\hline $\begin{array}{c}\text { Penguasa } \\
\text { an }\end{array}$ & \multicolumn{1}{|c|}{ Elemen } & \multicolumn{1}{c|}{ B } & $\begin{array}{c}\text { Ralat } \\
\text { Piawaii }\end{array}$ & Beta & T & Sig \\
\hline Kognitif & Silabus & .594 & .645 & .079 & .920 & .358 \\
& Jadwal & -.286 & .486 & -.045 & -.589 & .556 \\
& Kemudahan & -.448 & .455 & -.078 & -.984 & .326 \\
& Tempat & .184 & .565 & .027 & .325 & .746 \\
\hline
\end{tabular}




\begin{tabular}{|l|l|c|c|c|c|c|}
\hline & PdP & -1.959 & .959 & -.261 & -2.043 & .042 \\
& & & & & & \\
\hline & Analisis & $\mathrm{R}$ & $\mathrm{R}$ & Ubahsuai & Ralat & Kontrib \\
& Regresi & 0.170 & Ganda & $\mathrm{R}$ & Piawai & usi \\
& & & 2 & 0.00 & 3.99 & $0.5 \%$ \\
& & & 0.029 & 5 & & \\
\hline
\end{tabular}

Akhirnya analisis kontribusi elemen program PMET terhadap penguasaan MET anggota peserta secara keseluruhan (kognitif, afektif dan psikomotor) menunjukkan semua elemen adalah tidak signifikan yaitu nilai $\mathrm{P}^{-} 0.05$ kecuali elemen PdP. Seperti yang tertera di Jadwal 4.41, analisis elemen PdP terhadap penguasaan MET menunjukkan nilai Beta $=-0.285$, nilai $\mathrm{t}=2.240$ dan nilai $\mathrm{P}=0.026$. Analisis seterusnya menunjukkan nilai $\mathrm{R}$ $=0.194, \quad \mathrm{R}$ ganda dua $=0.038$ dan nilai ralat piawai $=7.11$. Nilai korelasi (R) yang ditunjukkan adalah kuat, yaitu terdapat hubungan di antara kedua variabel yang dikaji yaitu PdP dan penguasaan MET anggota peserta (keseluruhan). Gradien yang positif ini menunjukkan korelasi kedua-dua variabel adalah berkadar terus. Seterusnya apabila nilai pekali korelasi dikuasaduakan, maka $\mathrm{R}$ ganda dua $=0.038$. Data ini menunjukkan jumlah varians yang disatukan bersama oleh variabel tersebut ialah $3.8 \%$. Seterusnya setelah nilai $\mathrm{R}$ disesuaikan, didapati nilai $\mathrm{R}$ disesuaikan=0.014. Dengan ini dapatan analisis regresi berganda menunjukkan keberpengaruhan program PMET menerusi kontribusi elemen PdP program terhadap penguasaan MET anggota peserta (keseluruhan) $=1.4 \%$.

Jadwal 5: Analisis Regresi Berganda Kontribusi Elemen Program PMET Terhadap Penguasaan MET(Keseluruhan)

\begin{tabular}{|c|l|c|c|c|c|c|}
\hline Ujian & \multicolumn{1}{|c|}{ Elemen } & B & $\begin{array}{c}\text { Ralat } \\
\text { Piawaii }\end{array}$ & Beta & T & Sig \\
\hline $\begin{array}{c}\text { Penguasa } \\
\text { an MET }\end{array}$ & Silabus & 1.966 & 1.966 & .146 & 1.710 & .088 \\
& Jadwal & .680 & .680 & .060 & .786 & .432 \\
& Kemudahan & -.744 & -.744 & -.072 & -.916 & .360 \\
\hline
\end{tabular}




\begin{tabular}{|l|l|c|c|c|c|c|}
\hline & Tempat & - & -1.093 & -.090 & -1.085 & .278 \\
& PdP & 1.093 & -3.828 & -.285 & -2.240 & .026 \\
& & -3.828 & & & & \\
& & & & & & \\
\hline & Analisis & $\mathrm{R}$ & $\mathrm{R}$ & Ubahsuai & Ralat & Kontribu \\
& Regresi & 0.194 & Ganda & $\mathrm{R}$ & Piawai & si \\
& & 2 & 0.01 & 7.11 & $1.4 \%$ \\
& & & 0.038 & 4 & & \\
\hline
\end{tabular}

Daripada hasil penelitian yang hasilkan, dapat dirumuskan bahwa keberpengaruhan program PMET yang dijalankan dalam ATM adalah tidak begitu mempengaruhi pencapaian dalam penguasaan MET anggota peserta sama dengan penguasaan kognitif, penguasaan afektif, penguasaan psikomotor mahupun pencapaian keseluruhan MET. Data menunjukkan keberpengaruhan (keseluruhan) program PMET terhadap penguasaan MET anggota peserta adalah sebanyak $1.4 \%$.

Dari segi pecahan domain pula, kajian ini mendapati elemen jadwal telah memberi kontribusi yang signifikan terhadap penguasaan kognitif $(\mathrm{P}=$ 0.009) dengan jumlah sumbagan sejumlah $1.4 \%$, elemen silabus pula memberi kontribusi yang signifikan terhadap pencapaian afektif $(\mathrm{P}=0.14)$ sebanyak 3.6\% dan elemen PdP pula telah memberikan kontribusi yang signifikan terhadap pencapaian psikomotor $(\mathrm{P}=0.42)$ dengan jumlah kontribusi $0.5 \%$.

\section{Pembahasan}

Keberpengaruhan program PMET yaitu pengaruh elemen-elemen program PMET terhadap penguasaan MET anggota peserta dianalisis mengikuti metode regresi berganda. Regresi berganda digunakan sebagai metod analisis untuk melihat keberpengaruhan adaptasi teori Model Hammond dan Model Logik Universitas Winconsin yang dijadikan sandaran dalam kajian ini. Enam elemen pelaksanaan program PMET di analisis menggunakan ujian regresi berganda yaitu silabus, jadwal, kemudahan, tempat, kewangan, sokongan pemerintah dan PdP. Analisis regresi berganda ini digunakan bagi memenuhi objektif kajian dan menjawab persoalan tentang sejauhmanakah keberpengaruhan atau kontribusi program PMET terhadap penguasaan MET anggota peserta dalam ketiga-tiga domain 
kognitif, afektif dan psikomotor. Justeru, hasil analisis ini akan menjadi ukuran terhadap keberpengaruhan program PMET yang dijalankan dalam ATM.

Secara keseluruhannya kebanyakan dapatan kajian menunjukkan tiada perkaitan di antara variabel (elemen-elemen program) dan penguasaan MET (kognitif, afektif dan psikomotor) dengan dengan aras signifikan $\mathrm{P}^{-} 0.05$. Bagi penguasaan kognitif, data pada Jadwal 2 menjelaskan bahwa kesemua elemen yang terdapat dalam program PMET menunjukkan nilai yang tidak signifikan kecuali elemen jadwal. Oleh itu, terdapat kontribusi yang signifikan oleh elemen jadwal terhadap pencapaian kognitif anggota peserta program PMET. Dapatan ini menunjukkan jadwal program PMET yang dibentuk memperuntukkan masa yang mencukupi dan sesuai dengan untuk menjelasakan silabus semasa yang mengandungi 24 nilai dan etika tentara. Kesesuaian ini telah menjadikan elemen jadwal telah memberi kontribusi yang signifikan terhadap penguasaan kognitif anggota peserta dalam konteks silabus semasa. Dapatan ini seiring dengan kajian-kajian lepas seperti Fawziah yang mendapati jadwal yang disusun dengan teratur akan melancarkan proses pengajaran dan pembelajaran serta akan meningkatkan keberpengaruhan pengajaran. Walaupun demikian, kajian mendapati elemen silabus, kemudahan dan PdP tidak memberi kontribusi yang signifikan terhadap penguasaan kognitif.

Bagi penguasaan afektif, Jadwal 3 mendapati kesemua elemen program PMET menunjukkan hubungan tidak signifikan yaitu nilai $\mathrm{P}^{-} 0.05$ kecuali elemen silabus. Silabus yang memuatkan huraian 24 nilai dan etika tentara, peristiwa, contoh dan cerita realitas yang berlaku dalam ATM berkaitan isu moral dan etika. Skenario ini telah menyumbang kepada pencapaian afektif bagi anggota peserta karena mereka dikatakan dapat menghayati nilai-nilai dan etika tentara yang dipelajari serta membayangkan realitas kejadian seperti yang terkandung dalam silabus. Hasil penelitian ini sesuai dengan teori dan kajian lalu seperti Hurst, Kent. ${ }^{26}$ Mereka memaparkan fakta bahwa kekurangan sumber (termasuk silabus) dan kemudahan pembelajaran dapat mempengaruhi keberpengaruhan program atau tahap pencapaian pengajaran.

Seterusnya bagi penguasaan psikomotor pula, Jadwal 4 menunjukkan kesemua elemen program PMET menunjukkan perkaitan yang tidak signifikan yaitu nilai $\mathrm{P} 0.05$ kecuali elemen PdP. Fasilitator program PMET terdiri daripada pegawai dan pengajar pendidikan ATM yang memiliki

${ }^{26}$ Hurst (1981), Looking Holistically: The Conservation of Natural Resources Major. University of California, Berkeley: Conservation and Resource Studies Department. Kent. 1990, op.cit. 
pengetahuan dan pengalaman dalam aspek PdP. Rata-rata fasilitator memiliki kelulusan dan kemahiran dalam aspek pendidikan, khususnya dalam aspek pedagogi dan androgogi. Rumusan ini seiring dengan data kajian yang menunjukkan elemen PdP yang dikendalikan oleh fasilitator didapati mampu memberikan kontribusi kepada penguasaan MET anggota tentara dari aspek psikomotor. Selain daripada itu, latar belakang anggota tentara yang dikatakan sinonim dengan tingkah laku beretika, profesional, memiliki tahap disiplin dan beretika serta sentiasa dilatih dengan nilai MET telah menjadikan elemen PdP sebagai penyumbang utama kepada penguasaan aspek perlakuan ini. Hasil kajian ini bertepatan dengan teori dan literatur kajian-kajian lalu seperti Cage, Ulrich dan Cole, Reid, Shaw yang mengatakan pemilihan metode pengajaran yang tepat boleh memberi pengaruh kepada pencapaian tujuan sesuatu program dan metode pengajaran yang digunakan tidak sesuai dapat menimbulkan masalah kepada tahap pencapaian pelajar atau tingkahlaku pelajar. ${ }^{27}$

\section{Epilog}

Secara keseluruhannya, kajian mendapati hampir semua elemen (input dan output) program PMET menunjukkan hubungan yang tidak signifikan terhadap penguasaan MET anggota peserta (keseluruhan) kecuali elemen PdP. Analisis regresi berganda menunjukkan dampak penguasaan MET dalam kalangan anggota peserta adalah sangat rendah yaitu disumbangkan oleh elemen PdP $=1.4 \%$ (Jadwal 5). Dari segi pecahan mengikut domain pula, kontribusi program PMET yang tertinggi ialah terhadap pencapaian afektif yaitu sebanyak $3.6 \%$, oleh elemen silabus. Dengan itu terdapat kontribusi yang signifikan oleh elemen kurikulum terhadap penguasaan afektif (Jadwal 3). Diikuti kontribusi program PMET terhadap pencapaian domain kognitif yaitu sebanyak $1.4 \%$ oleh elemen jadwal. Dengan itu terdapat kontribusi yang signifikan oleh elemen jadwal terhadap penguasaan kognitif (Jadwal 2). Akhir sekali kontribusi yang terendah adalah terhadap penguasaan psikomotor dengan jumlah kontribusi $0.5 \%$ oleh elemen PdP. Justeru, terdapat kontribusi yang signifikan oleh elemen PdP terhadap penguasaan psikomotor (Jadwal 4). Sungguhpun peratusan kontribusi program PMET terhadap penguasaan MET anggota peserta amat kecil, namun terdapat elemen-elemen tertentu yang

27 Cage, N. (1975) The evaluation of teaching effectiveness and teacher education. Proceedings International for Education Seminar. 30 September-4 Oktober 1974, UNESCO. Ulrich dan Cole.1987, op.cit. Reid, The learning style preferences of ESL Students. TESOL Quarterly, 1987, 21(1), hlm. 87-111. Shaw. 1992, op.cit. 
menunjukkan pengaruh yang signifikan terhadap penguasaan MET dalam kalangan anggota peserta seperti yang telah dibincangkan (Jadwal 2 hingga $5)$.

Data mendapati kesemua penguasaan MET bagi domain kognitif, afektif dan psikomotor serta penguasaan MET keseluruhan adalah rendah dan boleh diklasifikasikan sebagai semua interaksi tidak berlaku pada tahap yang tinggi. Keadaan ini menjelaskan bahwa program PMET yang dilaksanakan dalam ATM memerlukan penelitian secara lebih mikro dan dilihat semula daripada segenap aspek yaitu bermula dengan elemen pelaksanaan program (input) dan peringkat proses PdP (output). Saranan ini sesuai memandangkan program PMET ini masih di peringkat percobaan yang mempunyai jurang yang besar dalam segenap aspek dan memerlukan input-input saran dari penelitian yang dijalankan untuk dibuat penambahbaikan.

\section{Daftar Pustaka}

Alias Baba. (1992). Statistik untuk penyelidikan dalam pendidikan dan sains sosial. Bangi: Penerbit Universiti Kebangsaan Malaysia.

Azizi dan Roslan (2000). Penilaian Terhadap Keberpengaruhan Perlaksanaan Program.

Azizi Yahya (2001b). The Using of Model Context. Input, Process and Products (CIPP) In Learning Programs Assessment. International Conference on Challenges and Prospects in Teacher Education, Concorde Hotel : Shah Alam, 16 \& 17 July 2001.

Azri (2009). Pelaksanaan Program Pendidikan Moral dan Etika Pemerintahan Medan Tentera Darat. Tesis Sarjana. Fakulti Pendidikan, Universitas Malaya.

Bebeau, M. (2002). The Defining Issues Test and the four component model: Contributions to professional education. Journal of Moral Education, 31(3), 271-295.

Berkowitz, M., \& Gibbs, J. (1983). Measuring the developmental features of moral discussion. Merrill-Palmer Quarterly, 29(4), 399-410. Retrieved October 13, 2008, from PsycINFO database.

Black, T. R. (1999). Doing quantitative research in the social sciences - an integrated approach to research design, measurement and statistics. London: Sage Publications.

Cage, N. (1975) The evaluation of teaching effectiveness and teacher education. Proceedings International for Education Seminar. 30 September-4 Oktober 1974, UNESCO. 
Davidson, M. (2005). Harness the sun, channel the wind: The promise and pitfalls of character education in the 21 st century. In D. K Lapsley \& F. C. Power (Eds.), Character psychology and character education (pp. 218-244). Notre Dame, IN: University of Notre Dame Press.

Frechtling, J.A ( 2007). Logic Modeling Methods in Program Evaluation. San Francisco, CA: Jossey-Bass.

Hammond, R. L. (1973). Evaluation at the local level. In B. R. Worthen \& J. R. Sanders (pnyt), Educational evaluation: theory and practice, hlmn. 157-169. Belmont, California: Wadsworth.

Hurst, John. (1981). Looking Holistically: The Conservation of Natural Resources Major. University of California, Berkeley: Conservation and Resource Studies Department.

Jabatan Arah Pendidikan (2008). Arahan Pentadbiran Pendidikan. Kuala Lumpur: ATM.

Arahan Pentadbiran Pendidikan ATM.

Kent, C.A., (1990). Introduction: educating the Heffalump. In: C.A. Kent (ed.), Entrepreneurship Education:Current Developments, Future Directions, New York: Quorum books, 1-26.

King, P. \& Mayhew, M. (2002). Moral judgment in higher education: insights from the Defining Issues Test [Electronic version]. Journal of Moral Education, 31(3), 247-270.

Lim, C.H. (2007). Penelitian pendidikan : Pendekatan kuantitatif dan kualitatif. Shah Alam : McGraw-Hill (Malayasia) Sdn. Bhd.

Markas Medan Tentera Darat (2012). Statistik Kes Jenayah dan Dadah

Pemerintahan Medan Tentera Darat, Sel Provos.

Martinelli-Fernandez, S. (2006). Educating honorable warriors. Journal of Military Ethics, 5(1), 55-66. Retrieved Thursday, February 22, 2007 from the Academic Search Premier database.

Mattox, J. (2005). The moral foundations of Army officership. 387-408. In Snider, D. \& Matthews, L. (2005). The future of the Army profession, 2nd Ed., New York: McGraw-Hill.

Moha Asri (1997). Pembangunan perindustrian di Malaysia : perkembangan dan permasalahan. Shah Alam : Fajar Bakti, Edisi 3.

Reece, I. \& S. Walker. (1997). Teaching Training and Learning: A Practical Guide (3rd ed). London: Business Education Publisher.

Reid, J. M. (1987). The learning style preferences of ESL Students. TESOL Quarterly, 21(1), page. 87-111. 
Shaw, M. (1992). Assesing Student Enterprise Capabilities. Evaluation Practice in the Enterprise for Higher Education Initutive. University of Bristol: 3-5.

Snider, D. (2008). Ethics and the human development of the soldier spirit. The Army Chaplaincy, 23-33.

Stufflebeam, D. L. \& Shinkfield, A. J. (1990). Systematic evaluation - a self instructional guide to theory and practice. Boston: Kluwer Nijhoff Publishing.

Trochim, W. K. (1999). Intoduction to evaluation. http://trochim.human. cornell.edu [13 April 2007].

Ulrich, T. A., and Cole, G. S. (1987), Toward More Effective Training of Future Entrepreneurs', JSBM, 25 (4), pp32-39.

Williams (2010). The Effect of Initial Entry Training on The Moral and Character Development of Military Police Soldiers. Ph.D Thesis, Walden University 